KACPER ŚWIERK

Badacz niezależny

\title{
Diabeł w sutannie, czyli ontologia pewnych bytów według Indian Matsigenka z peruwiańskiej Amazonii
}

$\mathrm{P}$ odczas mych badań terenowych we wschodnim Peru w 2001 r. Sarovani młody Indianin Matsigenka ze wspólnoty nawróconej na chrześcijaństwo przez protestanckich misjonarzy - opowiedział mi historię, którą, jak twierdził, usłyszał od innego Matsigenki (dalej nazywanego Kogonti), pochodzącego ze wspólnoty nawróconej przez misjonarzy katolickich ${ }^{1}$.

Według opowieści przekazanej mi przez Sarovaniego Kogonti miał zostać księdzem i w tym celu studiował w Rzymie. Studia trwały już długo i zbliżał się czas święceń kapłańskich. Pewnej nocy przyszło do niego dwóch ludzi, którzy wzięli go pod ręce i zabrali do innego pomieszczenia. Po chwili wszedł tam mężczyzna w stroju przypominającym sutannę. Gwałtownie rozpiął swój strój, ukazując członek w stanie erekcji. Następnie zwrócił się do Kogontiego - „Teraz odbędę z tobą stosunek". Kogonti, słysząc to, wyrwał się przytrzymującym go

\footnotetext{
${ }^{1}$ Moje badania terenowe wśród Matsigenków przeprowadziłem w porach suchych lat 2001, 2002, 2003. Badałem głównie relacje Indian żyjących w rozproszeniu w górnym biegu rzeki Paquiría z tymi żyjącymi w dużych skupionych osadach nad Urubambą, a także wykorzystanie zasobów naturalnych przez Matsigenków. Zebrałem też dane na temat etnozoologii Matsigenka oraz informacje związane $\mathrm{z}$ tematem niniejszego artykułu. Mój pobyt $\mathrm{w}$ terenie w 2001 r. był sfinansowany z własnych środków. Badania w 2002 r. były finansowane z grantu KBN w ramach projektu „Kierunki etnorozwoju w krajach andyjskich. Antropologiczne studium porównawcze: Ekwador - Peru - Boliwia", pod kierownictwem prof. dr. hab. A. Posern-Zielińskiego. Badania w 2003 r. odbyły się w ramach projektu: „Proyecto para la Reevaluación y Fortalecimiento de la Reserva Kugapakori Nahua", kierowanego przez brytyjsko-peruwiańską organizację Shinai Serjali, we współpracy z kilkoma innymi organizacjami. Projekt został sfinansowany przez: Garfield Foundation, The Netherlands Committee for the World Conservation Union, Nouvelle Planéte, Oxfam America i Rainforest Foundation US.
} 
mężczyznom i uciekł. Potem wrócił nad Urubambę (z opowieści nie wynika, w jaki sposób). Nie jest to jednak koniec tej historii. Kogonti nadal żyje w swej wspólnocie nad Urubambą i, jak twierdzi Sarovani, zdarza się, że kiedy któryś z misjonarzy schodzi do wspólnotowej przystani, by wyruszyć w podróż łodzią, Kogonti, który jest właśnie po wypiciu pewnej ilości masato (napój alkoholowy z manioku) lub mocniejszych trunków, podchodzi i zwraca się do niego po hiszpańsku: „Tsivato. Yo sé que te cacharon” („Homoseksualisto. Wiem, że oni odbyli z tobą stosunek"). Kiedy ksiądz mówi do niego: „Synu! Jesteś pijany. Co ty mówisz?”, on odpowiada - „Nie oszukasz mnie. Wiem dobrze, że odbyli stosunek z wami wszystkimi". Mówi to z przekonaniem i nigdy nie daje się zbić z tropu księdzu.

Historia ta zaintrygowała mnie. Ciekawość moją wzbudziło znaczenie, jakie zawarte w niej treści mają dla Indian Matsigenka. Kontynuując badania, zbierając dane w terenie jak i czytając literaturę poświęconą Matsigenkom, doszedłem do wniosku, że opowieść ta, choć dotyczy tematów związanych z instytucjami i ludźmi „z zewnątrz” (Kościołem katolickim, misjonarzami), jest w istocie głęboko osadzona w kosmologii Matsigenka, i tam należy szukać do niej odniesień.

Celem moim w niniejszym tekście jest przedstawienie odniesień tej historii do rzeczonej kosmologii (zwłaszcza przekonań na temat demonów kamagarini) oraz refleksja nad tym, dlaczego ukazuje ona misjonarzy czy księży katolickich w taki, a nie inny sposób.

W artykule przedstawiam krótką charakterystykę Matsigenków oraz zarys historii ewangelizacji tej grupy tubylczej. Następnie charakteryzuję kosmologię Matsigenków, aby zarysować kontekst, w którym sytuuję przekonania dotyczące demonów kamagarini. Po tym z kolei porównuję status ontologiczny demonów z takimż statusem homoseksualistów w kulturze dorzecza Dolnej Urubamby. W końcu analizuję historię Kogontiego w świetle przedstawionego materiału oraz niektórych zebranych przeze mnie wypowiedzi Matsigenków na temat duchownych katolickich.

\section{Matsigenka}

Indianie Matsigenka (Machiguenga) zamieszkują południową część peruwiańskiej Amazonii, mówią językiem należącym do południowej odnogi arawackiej rodziny językowej i liczą ok. 13 tys. osób. Większość Matsigenka mieszka w dorzeczach Urubamby i Madre de Dios, z czego 85\% nad Urubambą (Shepard 1999: 25). Ja prowadziłem badania w dorzeczu Dolnej Urubamby, pod tą nazwą rozumiem tu odcinek tej rzeki w dół od wielkiego wąwozu Pongo de Mainique.

Matsigenka są kopieniaczami (główne uprawy to słodki maniok, kukurydza i banany), a także łowcami, zbieraczami i rybakami. Znani są z egalitaryzmu, stoickości, unikania konfliktów i swoistego indywidualizmu, który wyraża się w tym, że tradycyjnie mieszkają oni w rozproszonych w lesie, niewielkich przysiółkach. Każdy z takich przysiółków jest zamieszkiwany przez rodzinę podstawową 
lub rozszerzoną od kilku do kilkunastu osób. Każda grupa rodzinna/domowa jest jakby autonomicznym społeczeństwem sama w sobie. Dzięki posiadanym poletkom jest niezależna ekonomicznie, a co za tym idzie - również politycznie. Tradycyjni przywódcy zwani tinkamintsi mają niewielką władzę i na ogół nie są w stanie zmusić ludzi do zrobienia czegokolwiek.

Dzisiaj jednak większość Matsigenka zamieszkuje w dużych skupionych osadach zwanych centros poblados ${ }^{2}$, w systemie comunidades nativas (wspólnot tubylczych) wprowadzonym przez państwo w 1974 r. i będącym oficjalnie uznaną formą tubylczej samorządności i posiadania ziemi przez Indian amazońskich w Peru. Większość osad mających obecnie status centros poblados wspólnot powstała w latach 50. i 60. XX w., w wyniku wysiłków misjonarzy protestanckich i katolickich, którzy starali się skupić w nich Indian po to, by móc ich skuteczniej nawracać i „cywilizować”. W wielu katolickich comunidades misjonarze rezydują do dziśs.

Życie w comunidades zdaje się być na pierwszy rzut oka zupełnie inne niż w leśnych przysiółkach. Są tu wybieralne władze, szkoła, bywa, że punkt medyczny. Ludzie mieszkają blisko siebie. Jednak po bliższym przyjrzeniu się, życie w centro poblado okazuje się podobne do życia „leśnych rodzin”. Decyzje dotyczące grup rodzinnych/domowych nadal są podejmowane w ich łonie, zbliżenie przestrzenne nie zawsze oznacza zbliżenie społeczne, a pozycja wybieralnego presidente wcale nie jest tak mocna, jak mogłoby się wydawać.

Poza tym sporo Matsigenków wciąż mieszka w tradycyjnych przysiółkach, bądź to oscylujących wokół centros poblados, bądź też oddalonych i niezwiązanych bezpośrednio z żadną comunidad nativa.

\section{Misjonarze}

Po podboju państwa Inków przez Hiszpanów w pierwszej połowie XVI w. sąsiadujące z Tawantinsuyu od wschodu tereny zamieszkane przez Matsigenka długo nie były kolonizowane. Dość szybko, ale na ogół marginalnie, stały się terenem działalności misjonarskiej. Pierwsze przedsięwzięcia misyjne na małą skalę, na obrzeżach obszarów zamieszkanych przez Matsigenka, miały miejsce już pod koniec XVI w. (Rosengren 2004: 31). Około 1650 r. w dolinie La Convención osiedlili się jezuici, którzy, po wyrzuceniu ich z Ameryki, zostali w 1768 r. zastąpieni przez dominikanów. Ci z kolei w 1798 r. ustąpili pola franciszkanom, którzy prowadzili działalność prozelityczną w regionie przez resztę okresu kolonialnego i przez znaczną część czasów republikańskich (do 1902 r.), kiedy to ponownie

2 Termin centro poblado ma w Peru też inne konotacje (nie będę tu rozwijać tego tematu), na co zwrócił mi uwagę anonimowy recenzent, jednak sami Indianie znad Dolnej Urubamby określają swe wioski w języku hiszpańskim jako centros poblados de las comunidades nativas. Wioska może też zasadnie zostać określona terminem comunidad [nativa], jednak słowo comunidad ma szersze konotacje. Może oznaczać ogół comuneros, ziemie wspólnotowe otaczające wioskę (terytorium wspólnoty) itd. Kiedy zaś ktoś mówi o centro poblado de la comunidad, jednoznacznie wiadomo, że chodzi o wioskę. 
zastąpili ich dominikanie (Rosengren, 1987: 39). Franciszkanie założyli misję hacjendę w Cocabambilla nad Górną Urubambą (w 1789 r.) i usiłowali założyć swe placówki poniżej Pongo de Mainique, ale bez większego powodzenia.

Wpływ działań misyjnych na Matsigenka w okresie kolonialnym był o wiele mniejszy niż w przypadku ich mieszkających bardziej na zachód krewnych Asháninka i Yánesha (Amuesha), którzy byli poddani wcześniejszej i intensywniejszej działalności prozelitycznej. Tylko pewna część populacji Matsigenka znalazła się pod bezpośrednim wpływem misji. Może to mieć związek m.in. z silnymi indywidualistycznymi tendencjami w kulturze Matsigenka, jednak również z tym, że przez dłuższy czas misjonarze obecni na terytorium Matsigenków mieli na celu nie tyle ewangelizację tych Indian, co raczej zdobycie środków na przedsięwzięcia prozelityczne w innych częściach Peru (Rosengren 2004: 26). Matsigenka przez długi czas spotykali się z duchownymi katolickimi raczej jako uczestnicy jarmarków odbywających się przy misyjnych hacjendach niż jako nawracane "Owieczki"4.

W 1742 r. Matsigenka wzięli udział w powstaniu Juana Santosa Atahualpy, które było elementem wieloetnicznego ruchu millenarystycznego. W znacznej mierze „oczyściło" ono obszary nad Urubambą i dżunglę środkowego Peru (Selva Central) z Białych tak skutecznie, że na większą skalę nie przybywali oni na te tereny aż do ok. połowy XIX w.

Najogólniej mówiąc, do początku XX w. misjonarze byli raczej słabo obecni na terenach zamieszkanych przez Matsigenka. Działalność misyjną wśród tych Indian zaczęto prowadzić na większą skalę od 1900 r., kiedy to pracę prozelityczną $\mathrm{w}$ tym regionie podjęli dominikanie. $\mathrm{W}$ latach $50 . \mathrm{XX} \mathrm{w}$. pojawili się też misjonarze protestanccy.

W 1900 r. dominikanie przejęli po franciszkanach zadanie ewangelizacji ludności tubylczej zamieszkującej tereny nad Urubambą i Madre de Dios i zaczęli dość aktywną działalność misyjną. Założyli placówki misyjne nad Górną i Dolną Urubambą, a także w dorzeczu Manu - Górnej Madre de Dios. W latach 1947-1948 ustanowili misję w Sepahua, dawnym regionalnym centrum handlu kauczukiem, które wyludniło się po spadku cen tego surowca ${ }^{5}$. Dominikanie wprowadzili szkolnictwo w swoich misjach. Pomimo że wielu spośród nich opanowało język matsigenka, kładli raczej nacisk na nauczanie hiszpańskojęzyczne ${ }^{6}$.

\footnotetext{
${ }^{3}$ Już wcześniej istniała tam hacjenda zarządzana przez zakonników (jezuitów), którzy jednak nie zajmowali się działalnością prozelityczną wśród miejscowej ludności.

${ }^{4}$ Niejako efektem ubocznym działalności misjonarzy w XVII i XVIII w. były wybuchy epidemii ospy, odry i innych chorób pochodzących ze Starego Świata, na które Indianie nie byli odporni. Spowodowało to spadek populacji i z pewnością, w wielu wypadkach, ponowne rozproszenie tych Indian, którzy przeżyli. Epidemie te, jak się zdaje, dotknęły Matsigenków w znacznie mniejszym stopniu niż ich zachodnich sąsiadów.

${ }^{5}$ Sepahua leży nad Dolną Urubambą, w okolicy zamieszkanej przez Indian Piro, ale niektóre jednostki i rodziny Matsigenka również zostały tam objęte działalnością prozelityczną.

${ }^{6}$ Postawa dominikanów wobec tubylców bywa krytykowana. Jak pisze Bennett (1991: 104): „Indianie byli - i generalnie wciąż są - postrzegani [przez misjonarzy] jako dzieci i leniwi ignoranci wysoce podatni na «diabelskie kuszenie»".
} 
W 1952 r. działalność nad Dolną Urubambą (później też nad Manu) rozpoczęła protestancka organizacja misyjna - Letni Instytut Lingwistyczny (ang. Summer Institute of Linguistics - SIL; hiszp. Instituto Lingüistico de Verano - ILV), w Peru znany także pod postacią Instituto Superior Pedagógico Bilingüe de Yarinacocha ${ }^{7}$. Protestanci rozwinęli edukację dwujęzyczną, opracowali alfabet dostosowany do fonetyki języka matsigenka, zajęli się tłumaczeniem Biblii i wykształcili w Yarinacocha koło Pucallpy pierwszych dwujęzycznych nauczycieli Matsigenka (zob. np. Davis 2002) ${ }^{8}$. Summer Institute of Linguistics działa na podstawie umowy z peruwiańskim Ministerstwem Edukacji.

Zarówno dominikanie, jak i misjonarze SIL-u przyczynili się do powstania skupionych, wielorodzinnych osad. Niekiedy, zwłaszcza nad Górną Urubambą, zaczynali swą działalność w miejscach, gdzie istniały już pewne skupiska Matsigenka - przy hacjendach czy centrach eksploatacji kauczuku. Jednak wiele dzisiejszych centros poblados de las comunidades nativas powstało praktycznie od podstaw jako osady misyjne.

Wskazując na różnice pomiędzy dominikanami i misjonarzami SIL-u, warto zwrócić uwagę na dwie sprawy. O ile dominikanie zwykle dosłownie zakładali osady misyjne, osiadając (często na stałe) w jakimś miejscu i skupiając wokół siebie okolicznych Matsigenka, o tyle misjonarze SIL-u promowali raczej indiańską samorządność, zakładając szkołę i umieszczając w niej wykształconych przez siebie tubylczych nauczycieli. Wokół szkoły skupiały się osady, w anglojęzycznej literaturze określane jako school communities (wspólnoty szkolne), które później zwykle otrzymały status comunidades nativas. Sami misjonarze SIL-u wizytowali, nadzorowali i wspomagali osady w pierwszych dekadach ich istnienia, niekiedy przebywali w nich przez dłuższy czas, ale nie zakładali $\mathrm{w}$ nich stałych misji z całym zapleczem. Dzisiaj Matsigenka protestanci mają własnych pastorów, a misjonarze-lingwiści co najwyżej odwiedzają co jakiś czas ich comunidades, aby prowadzić studia nad językiem przekładu Biblii9.

Każda z dwóch grup misjonarzy stworzyła wokół siebie osobną elitę Matsigenka. Istnienie tych elit przejawia się $\mathrm{w}$ dwóch niezależnych od siebie organizacjach Indian funkcjonujących dziś nad Urubambą. Jakkolwiek owe elity/ organizacje często są w stosunkach wzajemnie antagonistycznych, to antagonizm ten nie ma podłoża religijnego i Matsigenka generalnie nie przykładają wagi

\footnotetext{
7 Główna baza SIL-u znajduje się w Stanach Zjednoczonych Ameryki, skąd pochodzi też większość misjonarzy należących do tej organizacji.

${ }^{8}$ Misjonarze SIL-u zapewnili Indianom dostęp do metalowych narzędzi i wielu innych dóbr, opiekę medyczną (również poprzez szkolenie sanitarios), a także usiłowali uczynić z nich ludzi kompetentnych $\mathrm{w}$ gospodarce rynkowej, którzy potrafią być samowystarczalni $\mathrm{w}$ nowych warunkach. Jednocześnie jednak wykazywali bardzo fundamentalistyczne postawy, zwalczając elementy tubylczego światopoglądu, niepasujące do chrześcijańskiej-protestanckiej wizji świata. Baer (1994: 19) pisze o nich, że „nie szanują (...) tradycyjnej kultury, gdyż dla nich składa się ona $\mathrm{z}$ «przesądów» $\mathrm{i}$ «dzieła szatana»".

9 Protestanccy misjonarze, obecnie odwiedzający comunidades, należą formalnie do organizacji pod nazwą Misja Szwajcarska (ang. Swiss Mission; hiszp. Misión Suiza), którą jednak można traktować jako odgałęzienie SIL-u.
} 
do tego, czy ich współplemieniec, z którym mają do czynienia, jest nominalnie protestantem czy katolikiem.

Druga (ważniejsza) z interesujących nas tu kwestii to życie seksualne misjonarzy. Protestanccy misjonarze mogą uprawiać seks, jeśli robią to ze współmałżonkiem. Jest znamienne, że misjonarze SIL-u zwykle przybywali do kraju Matsigenków w parach małżeńskich i wręcz parami zapisali się w historii: Wayne (Walter) i Betty Snellowie, Harold i Patricia Davisowie. W przeciwieństwie do nich dominikanie nie przybywali parami, lecz jako samotni mężczyźni lub w grupach mężczyzn. $Z$ założenia nie wchodzą oni w związki małżeńskie i nie uprawiają seksu, a także nie prowadzą szerzej pojętego życia seksualnego. W dodatku w Sepahua pojawiła się specyficzna grupa kobiet - madres, czyli zakonnice. Wszystkie te okoliczności wpłynęły na to, że Matsigenka zwykli spoglądać na katolickich misjonarzy z pewną podejrzliwością.

\section{Kosmologia}

Matsigeńska wizja świata i relacji pomiędzy bytami go zamieszkującymi należy do typowych kosmologii amazońskich. Przedstawiam tu najważniejsze jej cechy i aspekty po to, aby zarysować kontekst, do którego będzie można odnosić informacje dotyczące demonów, homoseksualistów i katolickich duchownych.

Na początek warto zauważyć, że Matsigenka nie mają pojęcia ludzkości $\mathrm{w}$ naszym rozumieniu tego słowa. Istoty, które my, podmioty kultury Zachodu, sklasyfikowalibyśmy w jednym zbiorze jako ludzi, należą do różnych kategorii. Na przykład Matsigenka i inni nizinni Indianie zostali stworzeni przez dobrego (doskonałego) boga Tasorintsi, zaś andyjscy Indianie i Metysi (poñarona) oraz Biali (virakocha) są tworami niedoskonałego Kentivakori, który nieudolnie próbował rywalizować z Tasorintsim w dziele tworzenia. Matsigenka i Biali należą więc do dwóch różnych kategorii bytów (Rosengren 1987: 30-31; 2004: 86; zob. też: Descola 1992: 121). Granice pomiędzy tymi kategoriami są przekraczalne dzięki konsubstancjalizacji (podzielaniu substancji), której mogą ulec niedoskonałe byty, i przez to upodobnić się do Matsigenka. Wyrazem tego jest pewna liczba małżeństw pomiędzy Matsigenka a ludźmi pochodzącymi z Andów - zob. przykład opisany przez Deyermenjiana (Deyermenjian 1988: 70-74) ${ }^{10}$.

${ }^{10}$ Deyermenjian przedstawia przypadek andyjskiego Metysa zwanego Goyo, który wybrał życie z Matsigenkami zamieszkującymi trudno dostępny obszar wyżynnego lasu (selva alta) w regionie rzeki Toma (dorzecze Górnej Madre de Dios) i uległ znacznej „matsigenkizacji”. Jak pisze Deyermenjian: „Goyo przybył w ten region w 1979 roku, jako przewodnik ekspedycji francuskich poszukiwaczy fortuny. Była to prawdopodobnie pierwsza grupa ludzi z zewnątrz penetrująca ten obszar, od czasu gdy przybyli tu Machiguenga. [Goyo] powrócił tu sam następnego roku, zaczął się uczyć od [Matsigenków] Angela i Raimunda i, w ciągu kilku lat, osiągnął funkcjonalną płynność w języku machiguenga, posiadł umiejętność samodzielnego wykonywania typowych czynności służących utrzymaniu i założył dom z dwoma siostrami Machiguenga, «Josefiną» i «Carmen», jako żonami. Goyo, mówiąc o sobie, twierdzi, że jest obecnie Machiguengą" (Deyermenjian 1998: 77-78). Na marginesie warto tu podkreślić, że dla 
Światopogląd Matsigenka, podobnie jak światopogląd innych Indian Amazonii, można określić mianem perspektywistycznego (za Viveirosem de Castro 1998). Według ich wizji świata różne upodmiotowione istoty - takie jak ludzie, zwierzęta, zmarli, oraz to, co z zachodniego punktu widzenia określilibyśmy jako istoty nadprzyrodzone - widzą siebie jako istoty ludzkie oraz posiadające kulturę (tzn. np. osady, język, różne ozdoby, artefakty oraz różne przymioty społeczne). Jaguar np. widzi pitą przez siebie krew jako masato - trunek z manioku, pekari widzą błotniste zagłębienia, w których się tarzają, jako wioskę (Viveiros de Castro 1998; Lenaerts 2006: 11). Jednak istoty te z punktu widzenia innych istot niekoniecznie są widziane jako ludzie, np. - choć pekari postrzegają siebie jako ludzi, to przez ludzi są postrzegane właśnie jako pekari, zabijane i jedzone. Ludzie zaś mogą być postrzegani jako pekari, tapiry lub ryby przez wiele istot, takich jak jaguary, Kashiri (Księżyc) czy Inaenka - Matka Ospy, które polują na nich (lub ich dusze - isure) i zjadają ich.

Perspektywa/punkt widzenia wiąże się z ciałem, które dla Indian amazońskich nie jest czymś danym raz na zawsze, ale czymś przez cały czas będącym $\mathrm{w}$ procesie tworzenia się i modyfikacji poprzez dzielenie substancji - konsubstancjalizację. Ciało kształtuje się w zależności od tego, co kto je, z kim to je, z kim żyje i się uspołecznia, z kim uprawia seks. W wielu indiańskich opowieściach osoba, która zaczyna jeść pożywienie Innych (zwykle już widząc je jako pożywienie ludzkie), transformuje się w Innego cieleśnie. Przykładowo bohater opowieści Indian Yaminahua, który zobaczył palmowe orzeszki podane mu przez pekari jako pieczone mięso i zjadł je, częściowo zamienia się w pekari także cieleśnie wyrasta mu szczecina (Calavia Saéz 2001: 162-163). Literatura amazonistyczna obfituje w takie przykłady (zob. np. Anderson 1986: 86-91; Johnson 2003: 170; Opas 2005; Rosengren 2006: 87). W podobnej do yaminahuańskiej opowieści Matsigenków mężczyzna porwany przez pekari, a następnie schwytany przez ludzi nie potrafił mówić, gdyż będąc pekari, jadł okolcza - dziką trzcinę (Gynerium spp.). Dopiero kiedy dano mu do zjedzenia uprawną trzcinę cukrową (Saccharum officinarum), odzyskał zdolność komunikacji z ludźmi (Johnson 2003: 170). Przyjęcie jedzenia Innych widzianego już jako jedzenie ludzi często jest kluczowym momentem zmiany perspektywy i ciała w perspektywę i ciało Innego. Rodzaj pożywienia jest często wyznacznikiem tożsamości wśród Indian amazońskich. Tak na przykład Matsigenka identyfikują Indian Piro jako tych, którzy nie jedzą larw owadów, a Białych i Metysów jako tych, którzy jedzą czosnek, cebulę i ryż. Różnice pomiędzy dietą Matsigenków i Piro są dość niewielkie i obserwatorowi z zewnątrz mogą się jawić jako drugo- i trzeciorzędne szczegóły, ale z punktu widzenia tych Indian są one istotnymi wyróżnikami tożsamości, a z tego wynika cielesność i tożsamość Innych, która jest różna od "naszej”. Przebywanie z Innymi, przejęcie ich zwyczajów żywieniowych (jak i innych praktyk) prowadzi do przemian ciała i perspektywy. Nie zawsze muszą to być przemiany tak radykalne,

Matsigenka (a z pewnością dla ich szamanów) granice pomiędzy ludźmi a zwierzętami czy „bytami nadprzyrodzonymi” też nie są nieprzekraczalne. 
jak transformacja nieszczęsnego myśliwego w pekari. Przykładowo gantatsirira matsigeńscy łowcy niewolników (z lat 1930-1960), którzy zabijali i chwytali ludzi z własnej grupy etnolingwistycznej, byli tak okrutni, zdaniem moich informatorów, ponieważ przebywali wśród Piro, mieli żony i powinowatych Piro, zapewne też dzielili ich zwyczaje żywieniowe ${ }^{11}$.

Dzielenie substancji dokonuje się, jak już wzmiankowałem, nie tylko przez dzielenie zwyczajów żywieniowych (czy też dosłownie - dzielenie tego samego pożywienia), ale też przez życie $\mathrm{z}$ daną kategorią bytów, uczestniczenie $\mathrm{w}$ ich zajęciach, jak również przez akty seksualne i szeroko rozumiane życie seksualne.

Zarówno w opowieściach o przemianach w zwierzęta, jak i w relacjach z ludzkimi Innymi życie seksualne odgrywa istotną rolę. Na przykład myśliwy zamieniony w pekari w opowieściach Yaminahua i Matsigenka ma żonę (lub żony) pekari (Calavia Saéz 2001: 162-163; Johnson 2003: 170). Małżeństwo wiążące się przecież z seksem pociąga za sobą posiadanie powinowatych, a przez to dalsze dzielenie substancji z Innymi, czy będą nimi pekari, Piro czy też niespokrewnieni Matsigenka z sąsiedniego przysiółka. Opas (2005: 116-119) przytacza historię opowiedzianą jej przez sąsiadujących z Matsigenkami Indian Piro, w której pewien mężczyzna przyjmował pożywienie (niejadalne dla ludzi owoce) od łani mazamy amazońskiej (Mazama nemorivaga), którą widział jako młodą kobietę. W tym przypadku nie doszło do całkowitej transformacji mężczyzny w jelenia (ani jego perspektywy w jelenią mazamię), gdyż inni mieszkańcy wioski siłą zawlekli go do osady, gdzie szaman wyleczył go (tj., przywrócił mu ludzką perspektywę, którą ten stopniowo tracił) w ciągu kilkumiesięcznej terapii (Opas 2005: 116). Według rozmówców Opas (2005: 118) mężczyzna mógł zostać uratowany (przez i dla ludzi), wprawdzie spożywał nieczłowiecze jedzenie podawane mu przez łanię, ale jeszcze nie uprawiał z nią seksu. Akt płciowy z kobietą-mazamą ostatecznie przypieczętowałby jego przemianę $e^{12}$.

Wagę ma tu nie tylko to, z kim uprawia się seks. Wyznacznikiem odmienności może być też rodzaj seksu. Przykładowo gwałt (w języku matsigenka: noshikagantsi, w języku hiszpańskim: violación $)^{13}$ również implikuje dzielenie substancji, ale na innej zasadzie niż stosunki płciowe odbyte bez użycia przemocy. Gwałt jest domeną demonów - kamagarini, i jeśli ktoś spośród ludzi go popełnia, będzie przyrównany do demona.

${ }^{11}$ Piro, na przełomie XIX i XX w., zasłynęli jako łowcy niewolników dla białych patrones. Polowali oni głównie na Matsigenków. Stąd przypisywanie okrucieństwa gantatsirira właśnie wpływom Piro. Chwytanie przez Piro kobiet i dzieci Matsigenka, później wymienianych na różne towary z góralami andyjskimi bądź z białymi, miewało miejsce co najmniej od XVIII w. 12 Podobne historie opowiadają Indianie z obszaru Północno-Zachodniego Wybrzeża Ameryki Północnej. Collins (1952: 355), w trakcie swych badań wśród Skagitów ze stanu Waszyngton, zapisała historię o myśliwym, który spotkał w lesie piękną kobietę proponującą mu odbycie stosunku płciowego. Mężczyzna, po wahaniach, odmówił. Rano zorientował się, że kobieta była w istocie niedźwiedzicą. Rozmówca Collins dodał, że gdyby myśliwy dokonał innego wyboru i uprawiał seks z kobietą, sam stałby się niedźwiedziem.

13 Snell (2011: 805) podaje także matsigeński termin kamaritashitagantsi. 


\section{Kamagarini}

Kamagarini $^{14}$ (demony) zajmują w perspektywistycznym świecie Matsigenka miejsce dość szczególne. Mają one kształt bądź człekopodobny, bądź zwierzęcy (zależnie od rodzaju demona). W tym drugim przypadku demon nosi nazwę zwierzęcia, którego kształt posiada, plus przyrostek -niro. Demony żyją zwykle w okolicach trudno dostępnych górnych biegów rzek i strumieni, wydają charakterystyczny dźwięk eеeеeeeeeeeeii tom i, najogólniej rzecz biorąc, charakteryzują się tym, że gwałcą analnie ludzi, tym sposobem transformując ich w podobne sobie demoniczne istoty ${ }^{15}$.

Zgwałcenie przez demona jest opisywane przez Matsigenka na dwa sposoby. W pierwszym wypadku jest ono przedstawione jako coś, co ma miejsce w wymiarze cielesnym - fizycznym. Przykładem tego jest zanotowana przeze mnie opowieść o oshetoniro (demonie-czepiaku ${ }^{16}$ ), w której zestrzelona z łuku, pozornie konająca, nadnaturalnie wielka małpa znienacka zaczyna gwałcić jednego z myśliwych na oczach jego brata. Ten, nie mogąc już mu pomóc, ucieka, by ratować siebie i ostrzec szwagierkę. Zgwałcony mężczyzna sam potem staje się demonem i chodzi z umocowanym do siebie czepiakiem (wyglądając, jak gdyby niósł łup z polowania), szukając ludzi, których mógłby zgwałcić.

Drugi sposób opowiadania o zgwałceniu przez demony ukazuje to wydarzenie w wymiarze, który roboczo nazwę duchowym. Przykładem może być sytuacja opisana przez Bennett (1991: 185), kiedy to mężczyzna spotyka w lesie demona, który przybrał postać jego żony, i baraszkuje z kobietą, nie zdając sobie sprawy, że naprawdę jest to kamagarini penetrujący jego isure (duszę, duchową esencję) swym wielkim członkiem. Po powrocie do domu mężczyzna w rozmowie z żoną nawiązuje do spotkania w lesie, a ona zdziwiona mówi, że nie wie, o co chodzi, i że nie oddalała się od domu. Wówczas mężczyzna zdaje sobie sprawę, że jego dusza została „złamana” przez demona ${ }^{17}$. Wkrótce choruje i umiera, a jego isure, jak można domniemywać, zamienia się w kamagarini ${ }^{18}$.

Czasem demon, zaledwie pokazując się, dokonuje gwałtu na isure spotkanej osoby. Ilustruje to historia mężczyzny, którego nazwę tutaj Katsari, opowiedziana mi przez jego brata i żonę. Mężczyzna ten wybrał się na polowanie (obozowanie w lesie) wraz z członkami swej rodziny (było to w porze deszczowej 1997/1998). Towarzyszyli mu brat i żona. Według ich opowieści, podczas pobytu nad strumieniem zwanym Intsipashiari (niewielki dopływ Kipatsiari), nagle w koronach drzew pojawił się ogromny czepiak, „wielki jak tapir”. Był obwieszony licznymi, przyczepionymi doń młodymi, a biegnąc, powodował jakby powiew wiatru w koronach drzew (pojawieniu się demonów często towarzyszy wiatr). Podążał

${ }_{14}$ Słowo kamagarini jest etymologicznie związane ze słowem kamagantsi (umierać, śmierć), oznaczającym też tracenie przytomności czy bycie sparaliżowanym.

15 Taka transformacja to w matsigenka kamagarinitagantsi (zamieniać się w demona).

${ }^{16}$ Czepiak czarnolicy (Ateles chamek) - małpa o mięsie wysoko cenionym przez Matsigenków.

17 Czasownik oznaczający "łamanie” duszy to w regionalnym języku hiszpańskim romper. Nie jestem pewien jego matsigeńskiego odpowiednika.

${ }_{18}$ Bennett nie wspomina explicite o przemianie zgwałconego mężczyzny w demona. 
w stronę ludzi, nagle spadł i zniknął. Wkrótce po widzeniu demona Katsari źle się poczuł i dostał gorączki. Bez zwłoki zabrano go do przysiółka Mañokiari, gdzie spodziewano się zastać pewnego Matsigenkę - drwala, który miał łódź z silnikiem i mógł szybko zabrać chorego do najbliższej comunidad, aby tam zajął się nim sanitario. Po przybyciu na miejsce okazało się jednak, że drwal już odpłynął. Brat mężczyzny zabrał go więc do swego przysiółka, gdzie ten w krótkim czasie umarł. Zdaniem Indian śmierć ta była spowodowana przez demona oshetoniro ${ }^{19}$.

Jak widzimy, jedne opowieści Matsigenka mówią o fizycznym gwałcie analnym, zaś drugie jedynie o duchowym. Koniec końców i w jednych, i w drugich przypadkach zgwałcona zostaje dusza (isure/osure) osoby (która sama w sobie nie jest pozbawiona wymiaru cielesnego). Efekt również jest ten sam i, co najważniejsze, w obydwu przy padkach jest on dla Matsigenka równie rzeczywisty. Demony gwałcą zarówno mężczyzn, jak i kobiety (mężczyzn analnie, kobiety być może również waginalnie), ale uważa się, że kobiety są wobec nich bardziej bezbronne ze względu na swą „nieczystość" ${ }^{\prime 20}$. Konsekwencje zgwałcenia przez demona są dwojakie. Pierwszą jest śmierć osoby (jej ciała), a drugą zamiana jej duszy - esencji witalnej - $\mathrm{w}$ demona ${ }^{21}$. Zgwałceni przez demony sami stają się kamagarini i czyhają w lesie na ludzi. Jest to podstawowy, jeśli nie jedyny, sposób rozmnażania się kamagarinich. W przeciwieństwie do ludzi i innych bytów (jak np. przychylni ludziom, niewidzialni saankarite) demony nie mają rodzin. Multiplikują się, przerabiając Innych (którymi z ich punktu widzenia są w tym wypadku ludzie) w swoich poprzez gwałt. Jest to specyficzny wariant pewnej reguły w tubylczych amazońskich społeczeństwach i kosmologiach, w których tożsamość zawsze konstytuowana jest poprzez przetwarzanie Innego w siebie ${ }^{22}$.

Warto wspomnieć jeszcze, że misjonarze pracujący wśród Matsigenka, chcąc oddać ideę diabła, tłumaczą go na tubylczy język właśnie słowem kamagarini. Obecnie sami Matsigenka, chcąc przełożyć słowo kamagarini na język hiszpański, tłumaczą je jako diablo, demonio lub tunchi.

\footnotetext{
19 Strumień, nad którym nastąpiło spotkanie z demonicznym czepiakiem, nosił dawniej nazwę Intsipashiari - strumień liści drzewa intsipa (Inga sp.). Od czasu tamtego wydarzenia jest on nazywany Oshetoniroari (strumień oshetoniro) lub Kamagariniari (strumień kamagarini).

${ }^{20}$ Jak pisze Rosengren (1987: 87), kobiety, będąc „nieczystymi” (przez swą krew menstruacyjną), nie mogą, w przeciwieństwie do mężczyzn, liczyć na pomoc dobroczynnych bytów saankarite. Stąd, przebywając w lesie, są bardziej narażone na ataki demonów.

${ }^{21}$ W opowieści o oshetoniro mężczyzna zdaje się zachowywać swoje ludzkie ciało, lecz po gwałcie ma ono wyraźnie demoniczne usposobienie.

${ }^{22} \mathrm{~W}$ światopoglądach Indian nizinnej Ameryki Południowej swojskość i statyczna tożsamość są kojarzone z jałowością, a jednostka i społeczeństwo może się efektywnie reprodukować, jedynie zawłaszczając tożsamości z zewnątrz. To zawłaszczanie może odbywać się na różne sposoby: poprzez porwanie i adopcję osób z innych grup, rzeczywisty lub symboliczny kanibalizm, polowanie na głowy itp. Praktykom tym towarzyszy rytualna transformacja Innego (potencjalnego powinowatego, jeńca, zabitego wroga) w jednego ze swoich lub w komponent własnej, indywidualnej jaźni (zob. np.: Viveiros de Castro 1992, 2001, 2002; Fausto 1999, 2007; Taylor 1993: 671-675).
} 


\section{"Cioty", berdaches}

Kamagarini są nie tylko gwałcicielami. Są one również homoseksualistami. Choć gwałcą zarówno mężczyzn, jak i kobiety, a nawet podkreśla się, że kobiety są wobec nich bardziej bezbronne, to $\mathrm{w}$ większości opowieści zgwałconymi protagonistami są mężczyźni. Jest to z pewnością związane z tym, że mężczyźni znacznie częściej niż kobiety wychodzą do lasu, ryzykując tym samym spotkanie z kamagarini. Kamagarini jest więc (według naszych, zachodnich kategorii) homoseksualistą w sposób dwojaki - po pierwsze gwałci mężczyzn, po drugie, by stać się demonem, sam musiał być najpierw analnie zgwałcony ${ }^{23}$.

By należycie zrozumieć konotacje homoseksualności kamagarini, musimy mieć wgląd w to, czym homoseksualizm jest dla Matsigenka. Odwołam się tu też do postrzegania homoseksualistów przez innych mieszkańców dorzecza Dolnej Urubamby.

Homoseksualista to w języku matsigenka tsitamorori lub tsivato (to drugie być może od hiszpańskiego chivo). W regionalnej hiszpańszczyźnie zaś używa się określeń maricón, chivo i cabro ${ }^{24}$.

Jak słusznie zauważa Werner (1998), homoseksualizm nie jest kategorią międzykulturową (cross-cultural) i to, kto jest homoseksualistą, a kto nie, jest różnie oceniane w różnych kulturach. W kulturach północnoeuropejskich i ich pochodnych (jak np. kultura USA) jako homoseksualistę (geja) klasyfikuje się osobę, która uprawia seks z homoseksualnymi osobami tej samej płci (interesuje tu nas homoseksualizm męski), nie dociekając, czy podczas stosunku jest ona stroną „aktywną" czy „bierną”, ani jaką rolę płciową przyjmuje.

Jak pokazuje Werner, w większości społeczeństw świata jest jednak inaczej. Zarówno w kulturach południowych Europejczyków (i ich potomków - Latynosów), jak i w kulturach indiańskich (Werner podaje dwa tuziny przykładów z obu Ameryk) za homoseksualistę uważany jest mężczyzna będący stroną "bierną" w stosunku ${ }^{25}$. Przy tym homoseksualiści indiańscy jak i latynoscy są na ogół transwestytami czy transseksualistami. Nie spotkałem żadnych homoseksualistów/transseksualistów wśród Matsigenków ${ }^{26}$, ale ci, z którymi się zetknąłem

\footnotetext{
${ }^{23}$ Ktoś mógłby argumentować, że mężczyzna zgwałcony przez demona nie jest homoseksualistą, ponieważ sam tego nie chciał. Jednak w wypowiedziach Matsigenka zgwałcenie przez kamagarini jest wyrażane jako zrobienie z kogoś homoseksualisty. Mój informator, opowiadając w języku hiszpańskim historię o oshetoniro, wkłada w usta młodszego łowcy, który ostrzega swego brata, że wielka małpa może go zgwałcić, słowa: el va a hacer un maricón de ti (zrobi z ciebie homoseksualistę). W matsigenka używa się w tym kontekście wyrażenia: itsitamororikatake (on zamienia się w homoseksualistę [np. w wyniku gwałtu]).

${ }^{24}$ Na północ od dorzecza Urubamby, na obszarze departamentu Loreto, jest używane także słowo chimbombo.

25 Podział na uczestników aktu płciowego definiowanych jako strona „,bierna" i „czynna” jest zaczerpnięty z terminologii używanej niekiedy w kulturze zachodniej i niekoniecznie odpowiada terminom stosowanym w tym kontekście przez mieszkańców Amazonii. Dlatego też umieszczam te terminy w cudzysłowie.

${ }^{26}$ Tessmann, pisząc o blisko spokrewnionych z Matsigenka Indianach Campa (Asháninka i Ashéninka), twierdzi, że zdarzają się u nich akty płciowe pomiędzy młodzikami (karane
} 
w Sepahua nad Dolną Urubambą (Indianami Piro lub osobami pochodzącymi z mieszanych rodzin pirsko-metyskich), zachowywali się jak kobiety, często ubierali się jak one, nadawali sobie fantazyjne żeńskie imiona lub podkreślali swą „kobiecość" na inne sposoby. Latem 2003 r., kiedy Indianin Piro pracujący dla mnie jako kierowca łodzi z silnikiem poprosił dwóch stojących obok maricones, by pomogli mu przenieść nad rzekę silnik peque peque ${ }^{27}$ wraz z "ogonem” (długą rurą, do której mocuje się lekką, aluminiową śrubę), odparli mu - „My jako kobiety możemy nieść tylko śrubę".

Homoseksualista jest więc dla mieszkańców dorzecza Dolnej Urubamby osobą zniewieściałą, która podczas stosunku przyjmuje rolę identyfikowaną jako „bierną". By odróżnić homoseksualistę tego typu od homoseksualistów (gejów) rozumianych na sposób północnoeuropejski, proponuję tu stosowanie polskiego wyrazu "ciota” (oznaczającego w potocznym języku zniewieściałego homoseksualistę), a także pochodzącego z języka francuskiego terminu berdache używanego w literaturze (także antropologicznej) na oznaczenie podobnego typu homoseksualistów - transwestytów wśród Indian północnoamerykańskich ${ }^{28}$.

Co znamienne, mężczyźni mający stosunki $\mathrm{z}$ „,iotami” nie są nad Urubambą uważani za homoseksualistów. Jak wyjaśnił mi to po hiszpańsku pewien Piro z Sepahua - maricón es el que recibe, el que da es hombre (dosłownie: ciotą jest ten, kto

przez starszych), ale że prawdziwych homoseksualistów brak (No hay auténticos homosexuales) (Tessmann 1999 [1930]: 53). To, jak i fakt, że podczas moich badań nie spotkałem żadnych homoseksualistów u Matsigenków, sugeruje, że osoby tego typu są relatywną rzadkością wśród ludów Campa (sensu lato), do których Asháninka, Ashéninka i Matsigenka należą. Jednak R. Quispe - ichtiolog, który pracował nad Urubambą, twierdził w rozmowie ze mną, że spotkał homoseksualistów w co najmniej dwóch comunidades Matsigenka (Quispe, kontakt osobisty, 2011). Choć nie spotkałem wśród Matsigenków żadnych tsitamorori, to Indianie ci dobrze wiedzieli, kim oni są. Wielu Matsigenków było świadomych istnienia pirskich tsitamorori żyjących w Sepahua, wielu też, odwiedzając tę osadę lub przebywając w niej przez dłuższy czas, zetknęło się z nimi osobiście. Jeden z moich matsigeńskich informatorów, który ukończył szkołę w Sepahua, twierdził, że liczni spośród uczniów Matsigenka zakwaterowanych $\mathrm{w}$ tamtejszym internacie, mieli stosunki płciowe $\mathrm{z}$ tsitamorori. Utrzymywał on, iż wybierali seks z transseksualistami dlatego, że byli oni zawsze chętni i nie trzeba było zabiegać o nich jak o dziewczęta (np. nie było konieczne zapraszanie ich na oranżadę). Jeden z maricones, komentując przybycie nowego rocznika uczniów do szkoły z internatem w Sepahua, miał powiedzieć: "Oto przybywają moi mężowie".

${ }^{27}$ Peque peque to regionalna, onomatopeiczna nazwa niedużych silników o relatywnie niewielkiej mocy, używanych w Amazonii do napędzania łodzi. Oryginalnie produkowane przez firmę Briggs-Stratton jako silniki do amerykańskich kosiarek do trawy zostały zaadaptowane przez mieszkańców Amazonii, którzy dodali do nich „ogon” (długą, cienką rurę) i aluminiową śrubę. Silnik jest mocowany na rufie czółna w specjalnie dodanej desce z dziurą. Jak się wydaje, historia tego genialnego w swej prostocie wykorzystania silnika od kosiarki do potrzeb transportu rzecznego nie została nigdzie opisana (zob.: Gow 2001: 52).

${ }_{28}$ Termin berdache bywa też niekiedy używany w literaturze na oznaczenie tubylczych transseksualistów Mezoameryki i Ameryki Południowej (zob.: Endleman 1986: 213, przyp. 3). Mason np. (2000: 197) używa go w odniesieniu do tubylczych transseksualistów Panamy. Co do złożonej problematyki północnoamerykańskich berdaches - nie miejsce tu, by szerzej ją przedstawić. Na ich temat zob.: Whitehead (1989). 
otrzymuje [„,bierny” uczestnik stosunku], ten kto daje, jest mężczyzną) ${ }^{29}$. Nazywanie kogoś, kto odbywa stosunki z berdaches mianem „cioty”, byłoby uznane za zupełnie bezpodstawną obelgę. Mężczyzna taki może co najwyżej zasłużyć sobie na miano chivero - „amatora ciot". Jak się wydaje, większość chiveros funkcjonuje poza tym jako osoby heteroseksualne, ojcowie rodzin itd. (por.: Werner 1998: 3, 10).

Sytuując w tym kontekście demony kamagarini, możemy poczynić spostrzeżenie, że są one zarówno amatorami mężczyzn (gwałcą ich przez odbyt), jak i „ciotami” (większość z nich została demonami poprzez dokonany na nich gwałt). Ambiwalentny status [homo]seksualny demonów mógłbym ująć w hiszpańskojęzycznym wyrażeniu, że kamagarini es un maricón muy macho - jest bardzo męską (po męsku jurną) ciotą.

\section{Wypowiedzi Indian o duchownych katolickich i konkluzja}

Jak widzimy, historia przedstawiona na początku artykułu, wykazuje wiele podobieństw do opowieści o kamagarini. Wspólnym mianownikiem jest tu przede wszystkim gwałt. Warto jednak zauważyć, że historia ta nie jest jedyną słyszaną przeze mnie wypowiedzią Indian Matsigenka, w której duchowny jest przedstawiony jako istota demonopodobna. W niektórych z tych wypowiedzi Indianie niemal explicite sugerują związek czy wręcz tożsamość duchownych katolickich $\mathrm{z}$ demonami ${ }^{30}$.

Antropolog często buduje swoją wizję badanego społeczeństwa oraz rekonstruuje jego wizję świata, bazując na odnotowanych „anegdotycznych sytuacjach", kontekstowych zachowaniach czy wypowiedziach, które dopiero z czasem i doświadczeniem układają się w pewien wzór, który następnie jest wyrażany przez badacza (zob. np.: Shepard 1999: 2; Descola 1997: 145-146). Niemniej, jeśli chodzi o opinie o misjonarzach katolickich, Indianie, z którymi miałem do czynienia, wyrażali swe zdanie całkiem otwarcie, jakkolwiek nierzadko $\mathrm{w}$ formie pytania, przypuszczenia lub powoływania się na wypowiedzi innych. Co znamienne, w wypowiedziach tych misjonarze wcale nie byli przedstawiani jako istoty aseksualne. Pewien Piro z katolickiej osady mówił mi (wypowiadając się o jednym z seniorów miejscowej misji): „Padre $X$ na pewno miał bujne życie erotyczne. Był przecież bardzo młody, kiedy tu przyjechał”. Ten sam mężczyzna opowiadał o tym, jak ktoś podobno widział księdza odbywającego stosunek z zakonnicą podczas wizyty duszpasterskiej nad rzeką Serjali. Skomentował też - „Niektórzy powiadają, że zakonnice to żony księży”. Duże jego zainteresowanie wzbudzał również przypadek młodego dominikanina, który porzucił stan duchowny, aby ożenić się z mieszkanką Quillabamby. Wysłuchałem od niego

\footnotetext{
${ }^{29}$ W kulturach indiańskich i metyskich zachodniej Amazonii to strona „aktywna” (mężczyzna) jest definiowana jako dawca, zaś strona „bierna” (kobieta, berdache) jako biorca.

${ }^{30}$ Zastrzegam jednak, że większość przedstawionych w tekście wypowiedzi pochodzi bezpośrednio od Matsigenków zamieszkałych w protestanckich comunidades i być może ten fakt (np. coś co protestanccy misjonarze im opowiadali) ma jakiś wpływ na treść tych wypowiedzi.
} 
wielu podobnych komentarzy dotyczących księży, choć wcale nie prosiłem o nie, ani temat ten nie był głównym przedmiotem moich badań.

Całkiem podobnie było z Matsigenkami. Od jednego z nich usłyszałem historię o zgwałceniu uczennic przez księdza w szkole $\mathrm{z}$ internatem ${ }^{31}$. Jeden $\mathrm{z}$ młodych Matsigenków, z którymi pracowałem - Sarovani, parokrotnie zadawał mi pytania: „Kim są księża? Czy są berdachami (chivos, maricones)? Czy są demonami?”. Kiedy odpowiadałem mu, że nie, uśmiechał się jakby kpiąco. W 2001 r. odbyłem $\mathrm{z}$ nim podobną rozmowę na temat papieża. Niebacznie może pochwaliłem się, że ówczesny papież jest moim rodakiem. Siedzieliśmy z Sarovanim i drugim młodym Matsigenką (nazwę go tu Konkari) na odkrytej platformie domu nad rzeką Paquiría. Sarovani zaczął wypytywać mnie o papieża. Spytał m.in.: „Kim jest papież? Czy jest berdachem? Czy jest demonem?". Kiedy odpowiedziałem, że jest osobą ludzką jak my, uśmiechnął się kpiąco i rzucił spojrzenie Konkariemu ${ }^{32}$. Po paru innych pytaniach, które tu ominę, zapytał:

- A co będzie jak papież umrze? Będzie koniec świata?

- Nie - odpowiedziałem.

- To, co będzie?

- Wybiorą innego papieża.

- Kto będzie tym innym papieżem? - pytał dalej.

- Nie wiem, ale możliwe, że będzie nim Murzyn - odparłem z głupia frant. Użyłem hiszpańskiego słowa negro, które oznacza zarówno Murzyna, jak i kolor czarny. Sarovani był podekscytowany.

- Czarny (negro)? - powtórzył, rzucając porozumiewawcze spojrzenie Konkariemu.

- Tak, prawdopodobnie - odparłem.

Chwycił czarną plastikową torbę, która leżała obok.

- Tak czarny (negro), jak to? - zapytał. A zwracając się do Konkariego, powiedział w języku matsigenka: - Kisaari. Inti kamagarini („Czarny. To demon”).

Odpowiedziałem:

- Mówię o Murzynie (negro) - osobie afrykańskiego pochodzenia.

- Ale tak czarnym, jak to? - nie ustępował Sarovani, potrząsając torbą.

- Murzyn (negro), Afrykańczyk - powiedziałem. - Nie wiem, czy tak czarny (negro), jak to.

Sarovani spojrzał porozumiewawczo na Konkariego.

- Kisaari. Inti kamagarini („Czarny. To demon”) - powiedział znów w matsigenka.

Jak widać, Sarovani co najmniej przypuszczał (jeśli nie uważał), że papież ma coś z demonicznej natury. Stąd raczej kpiąco przyjmował moje wyjaśnienia, że

${ }^{31}$ Nie wiem, czy taki przypadek miał naprawdę miejsce, czy też jest to tylko opowieść zainspirowana plotkami.

${ }^{32}$ Moja odpowiedź niekoniecznie należała do najbardziej rozsądnych. Stwierdzenie, że papież jest istotą ludzką jak MY, jest niekoniecznie przekonywające dla Matsigenki, dla którego ja, mówiący te słowa, należę do virakochaegi - Białych - różnej od Matsigenków kategorii bytów o odmiennej genezie. 
jest on „osobą ludzką jak my” i rzucał porozumiewawcze spojrzenia Konkariemu. Potwierdzenie swych przypuszczeń znalazł on w mojej odpowiedzi dotyczącej prawdopodobieństwa, że kolejny papież będzie czarny (co, jak wiemy, się nie sprawdziło). Te kamagarini, które nie mają formy zwierzęcej, są opisywane jako czarne, humanoidalne istoty. Warto tu nadmienić, że ci znani mi Matsigenka, którzy bywali w Limie i spotykali Afroperuwiańczyków, wydawali się na ogół nie kojarzyć Murzynów z demonami tylko na podstawie ich ciemnej karnacji33. Sądzę, że w przypadku przytoczonej rozmowy zaważył kontekst. Osoba (czy kategoria bytu) już podejrzewana o bycie demonem, okazała się (w przypuszczalnej przyszłości) czarna, a więc taka, jakie są demony. Czarny kolor doskonale wpisał się w demoniczne konotacje, jakie miał papież dla Sarovaniego.

Wypowiedzi te rzucają dodatkowe światło na historię Kogontiego. Jak widzimy, katoliccy duchowni są właściwie explicite prezentowani jako byty demoniczne. Analogia mężczyzny w sutannie z opowieści Kogontiego do demonów nie jest więc przy padkowa. Jak wspomniałem w charakterystyce kosmologii, nie wszystkie istoty, które my (ludzie Zachodu) zaklasyfikowalibyśmy jako ludzkie, są w ścisłym sensie ludźmi dla Matsigenka. To, że jakaś istota jest zewnętrznie podobna do człowieka, nie przesądza o tym, że jest ona istotą ludzką (vide demon, który ukazał się mężczyźnie w lesie pod postacią żony). Tak więc księża, choć przypominają ludzi, mogą być $\mathrm{w}$ istocie demonami.

Nie będę przesądzać, czy przygoda Kogontiego miała miejsce naprawdę czy nie. Spróbuję jednak przeanalizować ją tak, jakby wydarzyła się naprawdę. Kogonti studiował w seminarium i przeżył tam próbę molestowania seksualnego. Istotne jest to, do jakich konkluzji po tym doszedł. Jak wynika z przedstawionych na początku tekstu portowych pogawędek Kogontiego z księdzem, nie potraktował on tego, co mu się przydarzyło, jako przypadku molestowania. Raczej odebrał to jako regułę, a mianowicie uznał, że każdy, aby zostać księdzem, musi być zgwałcony. Owo zgwałcenie jest nie tylko warunkiem transformacji alumna (czy innej osoby) w księdza, ale jest samym aktem tej transformacji. Alumn, by stać się księdzem, musi zostać zgwałcony. Wszyscy obecnie istniejący księża musieli więc być zgwałceni, aby stać się nimi („Wiem dobrze, że odbyli stosunek z wami wszystkimi"). Widzimy więc, że księża, według ontologii Matsigenka,

\footnotetext{
33 Było tak nawet, pomimo że przypisywali oni Afroperuwiańczykom posiadanie wielkich penisów (co jest również cechą kamagarini). Byłem raz świadkiem porównania do demona pewnej osoby (nie-Afroperuwiańczyka) w Limie. Pewnego wieczoru, w czerwcu 2002 r., wraz z Mariuszem Kairskim i Matsigenką Sarovanim chodziliśmy po centrum Limy, robiąc zakupy przed udaniem się w dorzecze Urubamby. Miało się ku zmierzchowi. W jednym miejscu, które mijaliśmy, na ulicy był wystawiony magnetofon, z którego dochodziły dźwięki salsy, a koło niego tańczył człowiek. Przechodnie rzucali jemu za to pieniądze do kartonowego pudełka. Tancerz nie miał nóg - jedynie kikuty od kolan w górę, którymi podpierał się, tańcząc na rękach. Jego karnacja nie była ciemniejsza niż u przeciętnego Metysa peruwiańskiego, ale twarz miał pobrudzoną jakby sadzą. Z pewnością był to brud, jaki zostawał mu na rękach po tym, jak tańcząc, opierał się dłońmi na asfalcie (a potem dotykał nimi twarzy). Włosy miał dość długie, czarne, drutowate, tworzące coś w rodzaju fryzury "á la młody Einstein”. Sarovani, spoglądając na tancerza, obszedł go ostrożnie półkolem. „Przypomina kamagarini” - powiedział, i nie wyglądało to na żart.
} 
multiplikują się podobnie jak demony - poprzez brutalną konsubstancjalizację. Stąd podejrzenie czy przekonanie Sarovaniego, że księża, a nawet papież, są demonami i berdachami. Jest to cokolwiek ironiczne, że misjonarze, tłumaczący ideę diabła na matsigenka słowem kamagarini, w oczach Indian sami należą do kategorii ontologicznej pokrewnej demonom. Aseksualność księży, zamiast postawić ich poza podejrzeniami, stała się asumptem do uznania ich za gwałtowne, demonopodobne istoty. Będąc widocznie aseksualnymi (np. nie mając żon), misjonarze nie zostali uznani przez Indian za „niewiniątka”. Raczej tubylcy uznali, że seksualność ta, niewidoczna na zewnątrz, realizuje się na innym polu, jako naznaczony przemocą stosunek płciowy pociągający za sobą transformację ofiary $\mathrm{w}$ istotę podobną do gwałciciela.

Jak widzimy, księża zostali wkomponowani w kosmologię Matsigenka jako istoty o statusie ontologicznym podobnym do demonów i doskonale wpasowali się w system przekonań istniejących na temat kamagarinich $^{34}$.

\section{Literatura}

Anderson, R.J. (1986). Cuentos folklóricos de los Ashéninca. Vol. 2. Perú: Instituto Lingüistico de Verano.

Baer, G. (1994). Cosmología y shamanismo de los matsiguenga (Perú Oriental). Quito: Ediciones Abya Yala.

Bennett, B.Y. (1991). Illness and Order: Cultural Transformation among the Machiguenga and Huachipairi, praca doktorska. New York: Cornell University.

Calavia Sáez, O. (2001). El rastro de los pecaríes: Variaciones míticas, variaciones cosmológicas e identidades étnicas en la etnología pano. Journal de la Société des Américanistes, $87,161-176$.

Collins, J. (1952). The Mythological Basis for Attitudes toward Animals among Salish-Speaking Indians. The Journal of American Folklore, 258(65), 353-359.

Davis, P. (2002). Los machiguengas aprenden a leer: Breve historia de la educación bilingüe y el desarrollo comunal entre los machiguengas del Bajo Urubamba. Lima: Pontificia Universidad Católica del Perú \& Instituto Lingüistico de Verano.

Descola, P. (1992). Societies of Nature and the Nature of Society. W: A. Kuper (ed.), Conceptualizing Society (s. 107-126). London: Routledge.

Descola, P. (1997). The Spears of Twilight: Life and Death in the Amazon Jungle. London: Flamingo.

Deyermenjian, G. (1988). Land Rights, Cultural Survival and Innovation Among Indigenous Peoples of the Western Amazon Basin: The Case of the Machiguenga, praca magisterska. Worcester: Clark University.

Endleman, R. (1986). Homosexuality in Tribal Societies. Transcultural Psychiatry, 23, 187-218.

${ }^{34}$ Chcę podkreślić tu, że na podstawie usłyszanych wypowiedzi czy odbytych rozmów nie mogę w uprawniony sposób powiedzieć, że wszyscy Matsigenka są przekonani o demonicznej naturze księży. Mogę jednak stwierdzić, że myślenie (o księżach) przez tych Matsigenków, z którymi rozmawiałem (jak i zapewne Kogontiego) jest strukturalnie par excellence matsigeńskie tzn. jest ono w 100 procentach kompatybilne z tym jak Indianie ci widzą świat różnych bytów i relacji pomiędzy nimi. Innymi słowy, wpisuje się ono całkowicie w „matsigeńską logikę". 
Fausto, C. (1999). Of Enemies and Pets: Warfare and Shamanism in Amazonia. American Ethnologist, 26(4), 933-956.

Fausto, C. (2007). Feasting on People: Eating Animals and Humans in Amazonia. Current Anthropology, 48(4), 497-530.

Gow, P. (2001). An Amazonian Myth and Its History. Oxford: Oxford University Press.

Johnson, A. (2003). Families of the Forest: The Matsigenka Indians of the Peruvian Amazon. Berkeley-Los Angeles-London: University of California Press.

Lenaerts, M. (2006). Substances, Relationships and the Omnipresence of the Body: An Overview of Ashéninka Ethnomedicine (Western Amazonia). Journal of Ethnobiology and Ethnomedicine, 2(49), 1-19.

Mason, P. (2000). Pretty Vacant: Columbus, Conviviality and New World Faces. W: J. Overing, A. Passes (eds.), The Anthropology of Love and Anger: The Aesthetics of Conviviality in Native Amazonia (s. 189-205). London-New York: Routledge.

Opas, M. (2005). Mutually Exclusive Relationships: Corporeality and Differentiation of Persons in Yine (Piro) Social Cosmos. Tipití. Journal of the Society for the Antropology of Lowland South America, 3(2), 111-130.

Rosengren, D. (1987). In the Eyes of the Beholder: Leadership and the Social Construction of Power and Dominance among the Matsigenka of the Peruvian Amazon. Göteborg: Göteborgs Etnografiska Museum.

Rosengren, D. (2004). Los matsigenka. W: F. Santos Granero, F. Barclay (eds.), Guía Etnográfica de la Alta Amazonía. T. 4 (s. 1-157). Panamá-Lima: Smithsonian Tropical Research Institute \& Instituto Francés de Estudios Andinos.

Rosengren, D. (2006). Matsigenka Corporeality, a Nonbiological Reality: On Notions of Consciousness and the Constitution of Identity. Tipití. Journal of the Society for the Antropology of Lowland South America, 4(1-2), 81-102.

Shepard, G.H. (1999). Pharmacognosy and the Senses in Two Amazonian Societies, praca doktorska. Berkeley: University of California.

Snell, B.A. (2011). Diccionario matsigenka-castellano con índice castellano, notas enciclopédicas y apuntes gramaticales. Lima: Instituto Lingüístico de Verano.

Taylor, A.C. (1992). Remembering to Forget: Identity, Mourning and Memory among the Jívaro. Man, 28(4), 653-678.

Tessmann, G. (1999 [1930]). Los indígenas del Perú nororiental. Investigaciones fundamentales para un estudio sistemático de la cultura. Quito: Ediciones Abya Yala.

Viveiros de Castro, E. (1992). From the Enemy's Point of View: Humanity and Divinity in an Amazonian Society. Chicago-London: The University of Chicago Press.

Viveiros de Castro, E. (1998). Cosmological Deixis and Amerindian Perspectivism. Journal of the Royal Anthropological Institute, 4(3), 469-488.

Viveiros de Castro, E. (2001). GUT Feelings about Amazonia: Potential Affinity and the Costruction of Sociality. W: L.M. Rival, N.L. Whitehead (eds.), Beyond the Visible and the Material: The Amerindianization of Society in the Work of Peter Rivière (s. 19-43). Oxford: Oxford University Press.

Viveiros de Castro, E. (2002). Imanência do inimigo. W: E. Viveiros de Castro (ed.), A Inconstância da alma selvagem. São Paulo: Cosac Naify.

Werner, D. (1998). On the Evolution and Cross-Cultural Variation in Male Homosexuality, www.gay-art-history.org/gay-literature/gay-studies/evolution-homosexuality/male-homosexuality-biological.html [dostęp: 2008].

Whitehead, H. (1989). The Bow and the Burden Strap: A New Look at Institutionalized Homosexuality in Native North America. W: S.B. Ortner, H. Whitehead (eds.), Sexual 
Meanings: The Cultural Construction of Gender and Sexuality (s. 80-115). Cambridge-Port Chester-Melbourne-Sydney: Cambridge University Press.

\section{SUMMARY}

Devil in Soutane: Ontology of Certain Beings according to the Matsigenka from the Peruvian Amazon

The Matsigenka Indians from the Peruvian Amazon believe in the existence of demoniac beings called kamagarini. These demons use to rape people anally, in this manner transforming them (or their spiritual essences - isure) into creatures of the same kind as the rapist. Catholic and protestant missionaries usually identify kamagarini with Western concept of devil. Surprisingly it seems that [at least some] Matsigenka perceive the catholic missionaries as, in important aspects, similar to the kamagarini demons.

Keywords: Matsigenka, Amazon, Peru, religious missions, indigenous cosmologies. 